\section{Effect of Pyridoxal 5-Phosphate in the Presence of Vanadyl Ions on the De-iodination of Thyroxine}

In the course of a recent investigation of the effects of metal ions on the de-iodination of thyroxine, it was suggested that sulphydryl groups are involved in the regulatory mechanism of de-iodination on the cellular level ${ }^{1,2}$.

Pyridoxal 5-phosphate has been shown to induce in vitro in the presence of certain cations, for example, vanadyl or aluminium, the catabolism of sulphydrylcarrying amino-acids ${ }^{3-5}$. It was of interest to check whether the pyridoxal phosphate-vanadium complex can affect the rate of deiodination in vivo.

Groups of 10 mice of local strain were used. $0 \cdot 1 \mathrm{ml}$. of the investigated material in saline solution was injected intraperitoneally. One hour after injection, the mice were injected with thyroxine labelled with iodine-131. Two hours later, the mice were killed and the amounts of labelled protein-bound iodine and of iodide in serum were determined as follows: the serum proteins were precipitated by trichloroacetic acid (TCA), in the presence of iodide hold-back carrier, and centrifuged. Then the supernatant and washings were collected and the iodide was precipitated with $1 \mathrm{M}$ silver nitrate. The labelled protein-bound iodine and the labelled silver iodide were counted, and the ratio of ${ }^{131} \mathrm{I} /{ }^{131} \mathrm{PBI}+{ }^{131} \mathrm{I}$ was calculated. This ratio increases when de-iodination is enhanced.

Oxygen consumption-rate was also determined and the procedure adapted was as follows: the measuring system consisted of an Erlenmeyer flask of $1,200 \mathrm{ml}$. which was attached to a differential manometer filled with a silicon fluid (density $1 \cdot 10$ ). A known volume $(100 \mathrm{ml}$.) of soda-lime inside a meshed container was introduced into the flask. Air-flow through the flask could be controlled by a stopcock. The measurements were carried out in a thermostat at $22 \pm 0.5^{\circ} \mathrm{C}$ using three mice at a time, the weight of which was determined. Before each measurement, air was passed through the flask for a few minutes, the stopcock was then closed, and the change in pressure was followed by the differential manometer.

The results given in Table 1 show that whereas pyridoxal phosphate alone has no effect on the rate of de-iodination, vanadyl ions have a certain effect of enhancement. However, when vanadyl ions are administered simultaneously with pyridoxal 5-phos. phate, the catalytic effect of vanadyl ions is doubled. It can be further seen from Table 1 that the oxygen consumption-rate diminishes as the rate of de-iodination increases.

The effect of thyroxine on pyridoxal phosphatelevel in liver ${ }^{6,7}$ and the effect of the latter compound on the deamination of thyroxine ${ }^{8}$ have been reported. Our observation is, however, of a different phenom. enon, namely, an effect on the rate of thyroxine deiodination. The fact that pyridoxal phosphate alone has no effect on thyroxine metabolism shows that, within the short time of our experiments, there is no interference with the different modes of action of pyridoxal phosphate. The activation of pyridoxal by vanadyl ions is rather specific to alpha-beta elimination $^{3, \theta}$ and strongly suggests that it decreases the level of sulphydryl groups in the organism.

The results corroborate our former observations ${ }^{2}$ that sulphydryl groups are involved in the process of de.iodination and that this process is not parallel to but reciprocal with the oxygen consumption-rate.

\section{Anbar \\ M. INBAR}

Weizmann Institute of Science

and the I.A.E.C. Research Laboratories, Rehovoth,

Israel.

1 Anbar, M., and Inbar, M., Bull. Israel Res. Counc., 11, A, 51 (1962).

${ }^{2}$ Anbar, M., and Inbar, M., Amer. J. Physiol. (in the press).

Snell, E. E., Vitamins and Hormomes, 16, 77 (Academic Press, New York, 1958)

- Bergel, F., Bray, R. C., and Harrop, K. R., Nature, 181, 1654 (1958). Bergel, F., Chemistry of Enzymes in Cancer (Ch. C. Thomas, Springfield, 1961).

- Horvath, A., Nature, 179, 968 (1957).

'Labaresse, J., Chatanger, F., and Tolles-Bergeret, B., Biochim. Biophys. Ácto, 39, 372 (1960). cf. Bull. Soc. Chim. Biol., 42, 51 (1960).

${ }^{8}$ Yamamoto, K., Ichiro, I, and Shimizu, S., Jap. J. Physiol., 10, 594 (1960).

- Ratsisalovanina, O., Chapeville, F., and Fromageot, P., Biochim. Biophys. Acta, 49, 322 (1961).

\section{PHYSIOLOGY}

\section{Effect of Cortisone on the Urinary Excretion of Histamine in the Hyper- thyroid Rat}

RECENT work has emphasized that histamine metabolism in the rat may be influenced by adrenocortical $^{1,2}$ and thyroid ${ }^{3,4}$ hormones. Various observations also indicate that these two groups of hormones may be functionally related in certain respects. It was therefore of interest to examine the action of cortisone on the urinary excretion of histamine in the hyperthyroid rat. It has been shown ${ }^{3}$ that the rat treated with thyroxine has a high urinary histaminelevel, and there is evidence that the high urinary histamine is the result of an increased rate of histamine synthesis ${ }^{4}$.

The urine of female, non-pregnant Sprague-Dawley rats (initial body-weight about $150 \mathrm{~g}$ ) was collected in 24-h portions under hydrochloric acid. The rats were given $10 \mathrm{~g}$ of a semi-synthetic, histamine-free food. The free urinary histamine ( $\mu \mathrm{g}$ histamine base per $24 \mathrm{~h}$ ) was determined by bioassay on the ileum of guinea pigs ${ }^{2}$. All rats were given aminoguanidine to prevent inactivation of histamine by histaminase ${ }^{4}$ (diamine oxidase).

Liothyronine was given subcutaneously in a dose of $0.05 \mathrm{mg} / \mathrm{rat} /$ day. Cortisone was given intramuscu-

Table 1. Effect of Pyridoxal 5-Phosphate in the Presence of Vanadium on the Rate of De-IOdination of Thyroxine and on

Compound

Controls

Pyridoxal phosphate

$\mathrm{VO}^{++}$

Pyridoxal phosphate $+\mathrm{VO}^{++}$
Dose per mouse ${ }_{(\mathrm{mg})}^{{ }^{181} \mathrm{I} /{ }^{131}} \mathrm{PBI}_{(\times 100)}{ }^{191} \mathrm{I}$

$\begin{array}{ll}- & 3 \cdot 0 \pm 0.28 \\ 0.4 & 2 \cdot 6 \pm 0.28\end{array}$

$\begin{array}{ll}0 \cdot 4 & 2 \cdot 6 \pm 0.28 \\ 0.2 & 3.7 \pm 0.28\end{array}$

$\begin{array}{ll}0.2 & 3 \cdot 7 \pm 0 \cdot 28 \\ 0.4 & 4.5 \pm 0.19\end{array}$

0.2

Difference

(\%)

$\overline{13} \cdot 3$

$+23 \cdot 3$
$+50 \cdot 0$
S.D.

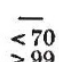

$<70$
$>99$

$>99$
$>99$ Oxygen consumption
rate (ml. $\left.\mathrm{O}_{\mathbf{2}} / \mathrm{min} / \mathrm{g}\right)$

Difference 0.065 0.065 0.039 0.028
(\%) 